\title{
Interaction between climate, flowering and production of dry coffee (Coffea arabica L.) in Minas Gerais
}

\author{
Lidiany dos Santos Soares $^{1}$ (D) Tiago Teruel Rezende $^{1}$ (D), Luiz Alberto Beijo² ${ }^{\text {ID }}$, Kleso Silva Franco Júnior ${ }^{3}$ (D)
}

\author{
${ }^{1}$ Universidade José do Rosário Vellano/UNIFENAS, Alfenas, MG, Brasil \\ ${ }^{2}$ Universidade Federal de Alfenas/UNIFAL, Alfenas, MG, Brasil \\ ${ }^{3}$ Empresa de Assistência Técnica e Extensão Rural do Estado de Minas Gerais/EMATER, Alfenas, MG, Brasil \\ Contact authors: lidysts@gmail.com; tiago.rezende@unifenas.br; luiz.beijo@unifal-mg.edu.br; kleso.junior@yahoo.com.br \\ Received in December 17, 2020 and approved in March 3, 2021
}

\begin{abstract}
Aiming to determine the interaction between climatic factors, flowering and yield of dry arabica coffee in municipalities in the regions of Southern Minas Gerais and Alto Paranaíba, both in the State of Minas Gerais, this study considered data from the harvest years 2008/2009 to 2017/2018, and climatic data analyzed according to the coffee phenological cycle. The determination of significant variables used the Stepwise method and the Akaike Information Criterion (AIC). The association of yield with climatic variables used a generalized linear model with gamma distribution and logarithmic function. Average flowering ( $20 \%$ to $50 \%$ of flowers per branch) used a logistic regression model. The productive variability of arabica coffee showed an association with the biennial cycle, the occurrence of medium and main flowering, flowering period and rains in bean formation. The occurrence of average flowering and the frequency of rainfall during bean formation enhanced coffee yield, at the same time as the increment in maximum temperature in vegetative bud formation reduced flowering and yield.
\end{abstract}

Key words: Phenological cycle of coffee; Temperature; Yield.

\section{INTRODUCTION}

Brazil has coffee production as one of the main economic activities of its agribusiness. As the world's largest coffee producer and exporter, it accounts for $35.3 \%$ of the world production, occupying a total planted area of 1.81 million hectares. In this scenario, Minas Gerais is responsible for $70.7 \%$ of the national production, with coffee planting in $55 \%$ of its municipalities. Furthermore, the state concentrates the largest cultivated area of the Arabica species, dedicating $69 \%$ of its agricultural space to it (Companhia Nacional de Abastecimento - CONAB, 2019).

Several agents can influence coffee yield, such as the use of fertilizers, pruning techniques, the spacing between rows and plants, climatic conditions, pests and disease control, among others (Dawid; Hailu, 2018; Verdin Filho, 2016; Carvalho; Chalfoun, 1998). Climatic factors have a vast impact on crop development, affecting its yield and quality (Silva et al., 2013). Meteorological components, especially temperature and rainfall, influence coffee yield, as they interfere in all phenological coffee stages, notably in flowering, fruiting and ripening (Bongase, 2017; Haggar; Schepp, 2012; Nunes et al., 2010). Such interferences can be favorable or decrease crop yield (Camargo, 2010).

Despite decades of important studies on the influence of climate on flowering and coffee yield (Mes, 1958; Camargo, 1985; Rena; Barros, 2004), the articles in the literature involve local amplitudes, data collection in the field, or both. Therefore, it is unknown how these variables relate to different municipalities belonging to certain expressive producing regions in the State of Minas Gerais. Martins et al. (2015), for example, evaluated the influence of climate on coffee yield and quality in Southern Minas Gerais. The study brings several relevant conclusions, such as the strong impact of water deficit and high temperatures on crop yield. However, the sampling was limited to the municipality of Muzambinho and the agricultural year of 2014, restraining the extension of the studyconclusions to the reality of Southern Minas Gerais and Alto Paranaíba.

Although the optimum annual temperature for arabica coffee planting is between 18 and $21^{\circ} \mathrm{C}$, specific cultivars can exhibit high yield and quality at temperatures above $24{ }^{\circ} \mathrm{C}$ under certain management conditions (Damatta et al., 2007). As the reproductive development of the plant is affected by temperature, light, soil, water availability, genotype, number of plants and carbon-nitrogen action in the soil (Damatta et al., 2007), flowering and yield of arabica coffee show geographic differences. Dutra Neto et al. (2017) reported that, in regions with mild temperatures, the plant physiology can be affected, resulting in late and varied flowering.

In addition, water availability can sometimes affect crop development more pronouncedly than temperature (Damatta et al., 2007). Finally, there is still a significant gap in the understanding of physiological processes, such as flowering and coffee biennial, as discussed in the review by Damatta et al. (2007).

All these factors justify the need for additional studies that can contribute to the development of regional policies to promote coffee cultivation, in addition to possible contributions to improve the management and the efficiency in the harvesting schedule. 
This study aimed to evaluate the interaction between climate, flowering and yield of dry arabica coffee in municipalities in the South and Alto Paranaíba, in the State of Minas Gerais. The regions have meteorological stations and permanent crop monitoring. Therefore, the conclusions of this research can guide studies in other municipalities and regions of the State of Minas Gerais and also help in estimating yield and crop scheduling (Arcila-Pulgarín et al., 2002).

\section{MATERIAL AND METHODS}

\subsection{Data source and scope}

Data on yield (bags per hectare) of dry arabica coffee from Minas Gerais were made available by the Technical Assistance and Rural Extension Company of the State of Minas Gerais - EMATER. Climatic, water deficit and flowering data were obtained through the Agrometeorological Monitoring System (SISMET) of the Regional Cooperative of Coffee Growers in Guaxupé - COOXUPÉ. The company collects the data through meteorological stations and a daily survey in all the cities studied. The analysis period is between harvest years $2008 / 2009$ to $2017 / 2018$.

The cities were: Alfenas (UTM coordinates: E; 403708 - N: 7630463, altitude: $827 \mathrm{~m}$ ), Cabo Verde (UTM coordinates: E: 354880 - N: 7622795, altitude: 940 m), Campestre (UTM coordinates: E : 371975 - N: 7597738, altitude: 1082 m), Carmo do Rio Claro (UTM coordinates: E: 379413 - N: 7679730 , altitude: $832 \mathrm{~m}$ ), Coromandel (UTM coordinates: E: 267916 N: 7955449, altitude: $962 \mathrm{~m}$ ), Guaxupé (UTM coordinates: E: 322818 N: 7643426, altitude: 870 m), Monte Carmelo (UTM coordinates: E: 237642 - N: 7927660, altitude: 912 m), Monte Santo de Minas (UTM coordinates: E: 295062 - N: 7655267, altitude: $910 \mathrm{~m}$ ), Nova Resende (UTM coordinates: E: 354506 - N: 7664777, altitude: $1200 \mathrm{~m}$ ) and Rio Paranaíba (UTM coordinates: E: 370199 - N: 7877253, altitude: $1120 \mathrm{~m}$ ), as shown in Figure 1.

These municipalities have similar sunstrokes and reach an annual average of 7.5 hours of insolation per day (Companhia Energética de Minas Gerais - CEMIG, 2012). These cities also represent $20 \%$ of the State's total production, with meteorological monitoring and data collection in the fields by technicians from Cooxupé. Therefore, the data were considered representative sources of the South and Alto Paranaíba regions in the State of Minas Gerais.

The data used were yield (bags per hectare), small flowering - between 0 and $20 \%$ of flowers per plant, average flowering - between $20 \%$ and $50 \%$, main flowering - 50\% and $100 \%$ of flowers per plant, initial and final flowering dates, considered from the first to the last flowering of the year (flowering period), minimum and maximum monthly temperatures $\left({ }^{\circ} \mathrm{C}\right)$, monthly average of relative air humidity $(\%)$, monthly rainfall $(\mathrm{mm})$ and monthly water deficit $(\mathrm{mm})$.

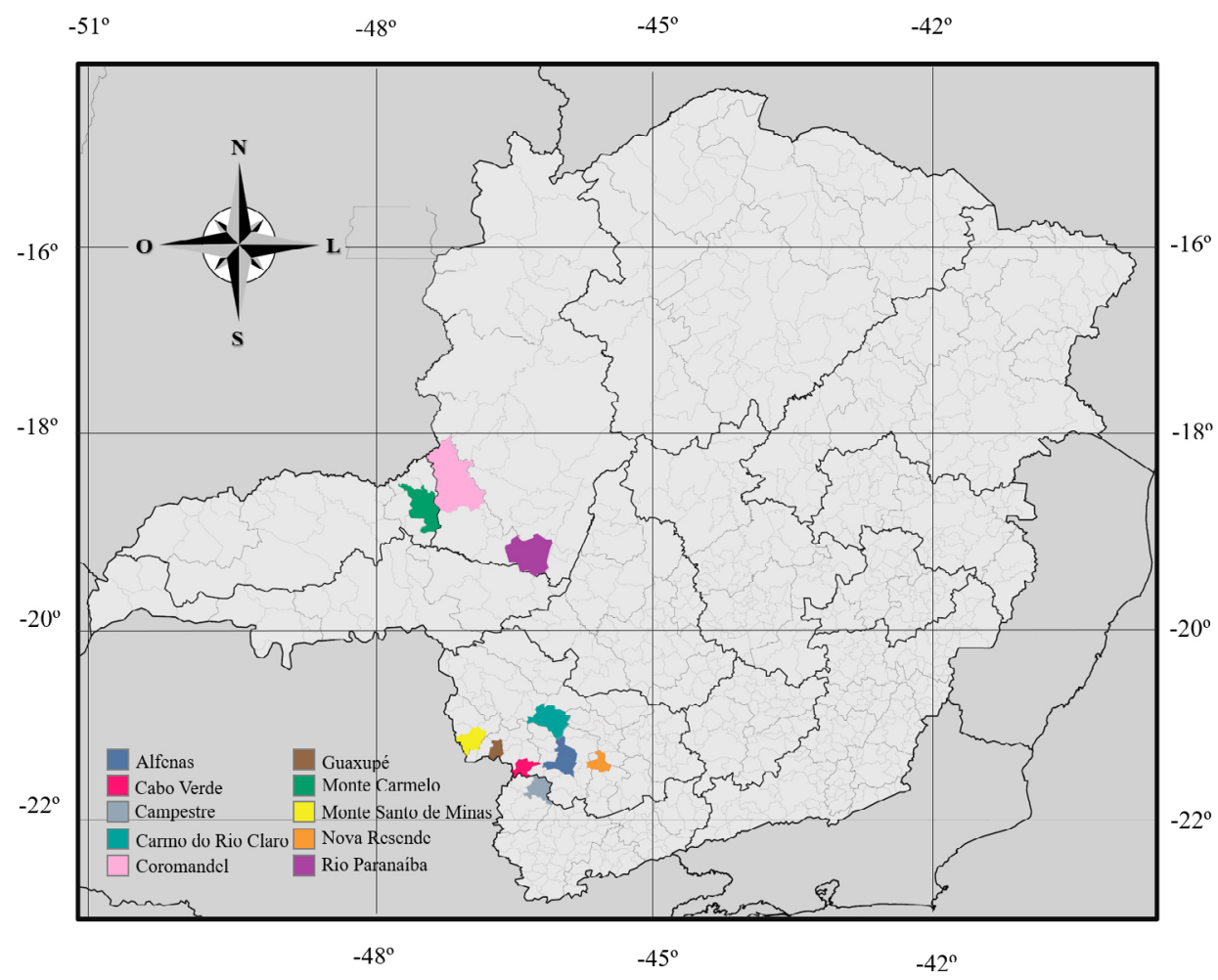

Figure 1: Location map of the municipalities studied in the State of Minas Gerais. 


\subsection{Statistical analysis}

The variables were analyzed according to the phenology of coffee proposed by Camargo and Camargo (2001), which takes two years to complete and presents vegetative and reproductive phases. The authors subdivided them into six distinct stages, considering two of them in the first phenological year (vegetative phase) and the other four in the second phenological year (reproductive phase), according to the tropical conditions in Brazil.

In the first year, the primary vegetative phase is linked to the formation of vegetative buds, generally occurring from September to March (Camargo, 1985). In the second vegetative phase, there is the induction, maturation, and dormancy of flower buds formed in the first phase, from April to August. The third phase (flowering, pellet and fruit expansion) begins in the second phenological year, with flowering after an increase in water potential in mature flower buds (Rena; Maestri, 1987). When fertilization occurs, the formation of small green berries (fruits) and their expansion begins. This phase covers the period from September to December (Camargo; Camargo, 2001). Fruit granulation takes place in the fourth phase, between January and March, followed by its ripening in the fifth phase, usually from April to June. The sixth and final phase takes place in July and August, with coffee resting and senescence after harvest.
The climatic data were correlated with flowering and yield, according to the phenological phases of coffee. The terminology "Year 1" is attributed to the first phase (formation of vegetative buds). The second and third phases (induction and maturation of the buds, flowering, small-green berries and fruit expansion) received the name "Year 2", and the fourth and last phase (bean formation) was called "Year 3", for statistical analysis.

The influence of 25 independent variables ( $x 1$ to $\mathrm{x} 25$ ) on yield (y1), given in bags/ha, was evaluated. Five of them are descriptive variables: $\mathrm{x} 1$ (municipalities), $\mathrm{x} 2$ (years of biannual), x3 (main flower), x4 (small flower), and x5 (medium flower). The biannual years were considered positive and negative for even and odd years, respectively (CONAB, 2019). The other independent variables are climatic data, that is, quantitative data. All data were evaluated for each municipality considering the crop year, which occurs from September to August. Quantitative variables (x6 to x25) were covariates in this study, as shown in Table 1.

Soil water deficit was measured by the Agrometeorological Monitoring System (SISMET) of COOXUPÉ, according to the estimation of the water balance proposed by Camargo (1971). The averages of the quantitative variables studied were raised for each municipality, as shown in Table 2.

Table 1: Quantitative variables adopted in the correlation between climate, yield and coffee blooms from 2007/2008 to $2018 / 2019$.

\begin{tabular}{|c|c|c|}
\hline Code & Variable & Unit \\
\hline $\mathrm{x} 6$ & Flowering period & Day \\
\hline $\mathrm{x} 7$ & Lowest minimum temperature from May to July - Year 2 & ${ }^{\circ} \mathrm{C}$ \\
\hline $\mathrm{x} 8$ & Average minimum temperature from May to July - Year 2 & ${ }^{\circ} \mathrm{C}$ \\
\hline $\mathrm{x} 9$ & Highest maximum temperature from Sep to Dec - Year 1 & ${ }^{\circ} \mathrm{C}$ \\
\hline $\mathrm{x} 10$ & Highest maximum temperature from Jan to April - Year 2 & ${ }^{\circ} \mathrm{C}$ \\
\hline $\mathrm{x} 11$ & Highest maximum temperature from May to Aug - Year 2 & ${ }^{\circ} \mathrm{C}$ \\
\hline $\mathrm{x} 12$ & Highest maximum temperature from Jan to March - Year 3 & ${ }^{\circ} \mathrm{C}$ \\
\hline $\mathrm{x} 13$ & Average maximum temperature from Sep to Dec - Year 1 & ${ }^{\circ} \mathrm{C}$ \\
\hline $\mathrm{x} 14$ & Average maximum temperature from Jan to April - Year 2 & ${ }^{\circ} \mathrm{C}$ \\
\hline $\mathrm{x} 15$ & Average maximum temperature from May to Aug - Year 2 & ${ }^{\circ} \mathrm{C}$ \\
\hline $\mathrm{x} 16$ & Average maximum temperature from Jan to March - Year 3 & ${ }^{\circ} \mathrm{C}$ \\
\hline $\mathrm{x} 17$ & August humidity - Year 2 & $\%$ \\
\hline $\mathrm{x} 18$ & Sum of rain from Sep to Dec - Year 1 & $\mathrm{~mm}$ \\
\hline $\mathrm{x} 19$ & Sum of rain from Jan to April - Year 2 & $\mathrm{~mm}$ \\
\hline $\mathrm{x} 20$ & Sum of rain from May to Aug - Year 2 & $\mathrm{~mm}$ \\
\hline $\mathrm{x} 21$ & Sum of rain from Jan to March - Year 3 & $\mathrm{~mm}$ \\
\hline $\mathrm{x} 22$ & Highest water deficit from Sep to Dec - Year 1 & $\mathrm{~mm}$ \\
\hline $\mathrm{x} 23$ & Highest water deficit from Jan to April - Year 2 & $\mathrm{~mm}$ \\
\hline $\mathrm{x} 24$ & Highest water deficit from May to Aug - Year 2 & $\mathrm{~mm}$ \\
\hline $\mathrm{x} 25$ & Highest water deficit from Jan to March - Year 3 & $\mathrm{~mm}$ \\
\hline
\end{tabular}


Table 2: Averages of climatic and flowering variables according to municipalities.

\begin{tabular}{|c|c|c|c|c|c|c|c|c|c|c|}
\hline Variables & ALF. & C.V. & CAMP. & C.R.C. & COR. & GUA. & M.C. & M.S.M. & N.R. & R.P. \\
\hline y1 & 27.2 & 31.4 & 23.3 & 24.9 & 30.2 & 21.1 & 32.7 & 17.1 & 30.2 & 30.4 \\
\hline$x 6$ & 40.8 & 47.6 & 45.7 & 40.6 & 32.4 & 43.0 & 37.9 & 39.6 & 38.4 & 32.3 \\
\hline $\mathrm{x} 7$ & 6.2 & 1.9 & 5.9 & 5.7 & 9.6 & 3.4 & 8.4 & 6.2 & 6.33 & 8.0 \\
\hline $\mathrm{x} 8$ & 12.8 & 9.6 & 12.1 & 12.4 & 15.1 & 11.9 & 14.4 & 13.6 & 13.3 & 14.2 \\
\hline $\mathrm{x} 9$ & 35.3 & 32.7 & 32.6 & 34.6 & 35.1 & 34.9 & 35.2 & 34.7 & 32.7 & 33.9 \\
\hline $\mathrm{x} 10$ & 34.1 & 32.0 & 31.0 & 33.6 & 33.2 & 33.2 & 33.2 & 33.1 & 31.1 & 32.4 \\
\hline $\mathrm{x} 11$ & 30.7 & 29.6 & 28.7 & 31.4 & 31.7 & 31.7 & 32.2 & 31.5 & 28.8 & 31.2 \\
\hline $\mathrm{x} 12$ & 34.2 & 32.0 & 30.9 & 33.6 & 32.8 & 33.2 & 33.2 & 33.1 & 31.0 & 32.5 \\
\hline $\mathrm{x} 16$ & 29.0 & 27.1 & 26.3 & 28.8 & 29.1 & 28.6 & 29.8 & 28.5 & 26.3 & 28.4 \\
\hline $\mathrm{x} 14$ & 28.8 & 26.9 & 26.1 & 28.9 & 28.3 & 28.2 & 28.9 & 28.1 & 25.9 & 28.1 \\
\hline $\mathrm{x} 15$ & 24.9 & 23.6 & 230.7 & 25.3 & 26.3 & 25.1 & 26.9 & 25.3 & 22.6 & 25.4 \\
\hline $\mathrm{x} 16$ & 29.4 & 27.3 & 26,6 & 29.3 & 28.4 & 28.8 & 29.2 & 28.7 & 26.4 & 28.4 \\
\hline $\mathrm{x} 17$ & 57.1 & 70.5 & 66.3 & 63.9 & 50.7 & 62.1 & 55.1 & 61.1 & 62.2 & 56.6 \\
\hline $\mathrm{x} 18$ & 537.5 & 732.0 & 681.6 & 612.8 & 699.6 & 662.6 & 711.0 & 689.7 & 683.8 & 724.1 \\
\hline x19 & 638.2 & 900.0 & 747.7 & 723.8 & 792.0 & 764.5 & 797.5 & 743.5 & 783.6 & 747.8 \\
\hline $\mathrm{x} 20$ & 103.6 & 192.3 & 157.7 & 133.8 & 78.2 & 136.9 & 105.0 & 134.1 & 139.1 & 86.1 \\
\hline $\mathrm{x} 21$ & 546.2 & 803.8 & 630.6 & 574.6 & 676.2 & 653.6 & 663.8 & 635.0 & 693.8 & 674.2 \\
\hline$x 22$ & 33.6 & 22.4 & 23.1 & 35.0 & 53.1 & 26.8 & 57.5 & 26.5 & 22.1 & 41.5 \\
\hline$x 23$ & 17.2 & 5.6 & 9.5 & 9.8 & 12.2 & 6.3 & 14.6 & 8.6 & 5.1 & 17.6 \\
\hline $\mathrm{x} 24$ & 41.7 & 19.1 & 18.8 & 34.2 & 58.8 & 30.5 & 54.2 & 35.2 & 30.1 & 48.8 \\
\hline $\mathrm{x} 25$ & 8.1 & 2.1 & 4.4 & 5.9 & 8.7 & 3.1 & 4.9 & 5.9 & 2.3 & 9.5 \\
\hline
\end{tabular}

ALF=Alfenas - C.V. $=$ Cabo Verde - CAMP $=$ Campestre - C.R.C. $=$ Carmo do Rio Claro - COR. $=$ Coromandel - GUA $=$ Guaxupé - M.C. $=$ Monte Carmelo - M.S.M. $=$ Monte Santo de Minas - N.R.=Nova Resende - R.P= Rio Paranaíba.

The data were consolidated for analysis, since the effects of the variables were significant for all municipalities. Thus, the study considered as classificatory the biennial, main, small and medium flower variables, evaluating it according to the presence or absence in the period. In the exploratory analysis, descriptive statistics of the variables were performed, such as the mean, median, minimum, and maximum values (Table 3).

Some climatic variables showed multicollinearity; therefore, they could not comprise the study at the same time. Two general models were then analyzed, using the climatic data that presented an absolute value of the linear correlation lower than $0.5(|\mathrm{r}|<0.5)$ as covariables, as shown in Figure 2.

The Stepwise method was used to determine the important variables in the general models, which uses the Akaike Information Criterion (AIC) in the combination of the variables to select the most adjusted model. The best model is the one with the lowest AIC (Emiliano et al., 2014).

The generalized linear model, with gamma distribution and logarithmic link function, was used to verify the association between coffee yield (continuous variable) and climatic variables. As the occurrence of average flowering is a dichotomous variable (yes or no), the data were submitted to logistic regression. Deviance was analyzed using the ChiSquare test (Collet, 1991) to check the significance of the model and the quality of the fit. All analyses and adjustments used the R software (R Core Team, 2020).

Despite not showing any significance in the results, the variable $\mathrm{x} 18$ was maintained in the model, as it contributed to obtaining a lower AIC.

\section{RESULTS}

Throughout the ten crop years analysis of coffeeproducing municipalities in the State of Minas Gerais, it was observed that climatic conditions have a close influence on flowering and, consequently, on yield. The maximum temperature from September to April (included in the first phenological phase), when leaf buds are forming, was negatively correlated with yield.

The existence of mean flowering was also influenced by the maximum temperature from September to December, which can be harmful in certain periods, as it acts in the initial phase of the plant vegetative cycle. Furthermore, extended flowering periods are detrimental to yield, once they affect fruit uniformity. 
Table 3: Exploratory analysis of quantitative variables of climate, flowering and yield.

\begin{tabular}{ccccc}
\hline Variable code & Median & Mean & Minimum & Maximum \\
\hline y1 & 28.0 & 26.9 & 10.0 & 41.0 \\
x6 & 42.0 & 39.7 & 8.0 & 107.0 \\
x7 & 6.2 & 6.2 & 0 & 11.9 \\
x8 & 13.0 & 13.0 & 8.3 & 15.8 \\
x9 & 34.2 & 34.3 & 26.0 & 37.9 \\
x10 & 32.9 & 32.8 & 29.5 & 36.2 \\
x11 & 31.0 & 30.8 & 26.6 & 33.8 \\
x12 & 32.8 & 32.8 & 29.5 & 36.2 \\
x13 & 28.2 & 28.3 & 24.9 & 31.6 \\
x14 & 28.1 & 27.9 & 24.7 & 31.0 \\
x15 & 25.2 & 24.9 & 21.3 & 28.1 \\
x16 & 28.5 & 28.3 & 25.2 & 31.0 \\
x17 & 60.2 & 60.4 & 45.4 & 77.1 \\
x18 & 671.0 & 672.5 & 9.4 & 1734.0 \\
x19 & 731.2 & 761.5 & 307.4 & 1757.6 \\
x20 & 113.0 & 124.0 & 5.0 & 325.0 \\
x21 & 619.2 & 652.9 & 241.2 & 1596.8 \\
x22 & 32.6 & 34.8 & 0 & 90.8 \\
x23 & 7.10 & 0.8 & 0 & 9.6 \\
x24 & 41.0 & 38.1 & 1.5 & 70.0 \\
x25 & 0 & 5.6 & 0 & 69.6 \\
\hline
\end{tabular}

However, these periods are necessary to increase the possibility of mean flowering, which is positively related to yield. The occurrence of rain from January to March is also important, since the fruits are in the final stage of bean formation. Analyzing yield, the Selec 1 and Selec 2 models showed a similar performance, according to the AIC values (Table 4).

The effects of climatic variables were significant for all municipalities $(p<0.05)$, resulting in a single analysis for the two regions studied. As for the production cycle, the influence of biennial periods was verified, which was associated with periods of lower yield in $49 \%$ of cases and higher yield in $51 \%$ of cases.

Models 1 and 2 showed a positive correlation between yield and the variables mean flowering $(\mathrm{p}<0.05)$ and sum of rain ( $<<0.1$ and $\mathrm{p}<0.05$ ) in the bean formation phase (Tables 5 and 6 ). Mean flowering occurred in $52 \%$ of the crop years analyzed, in contrast to small flowering, that occurred in $30 \%$ of the analyzed crop years and did not show significant results for production. The rain that occurred from January to March assumed average values of $652.9 \mathrm{~mm}$.

The flowering period (x6) negatively impacted coffee yield $(\mathrm{p}<0.05)$. Besides, there was a negative correlation within the maximum temperature from September to December (x13) and January to April (x10), and yield ( $<0.01, \mathrm{p}<0.05$ ) (Table 7).

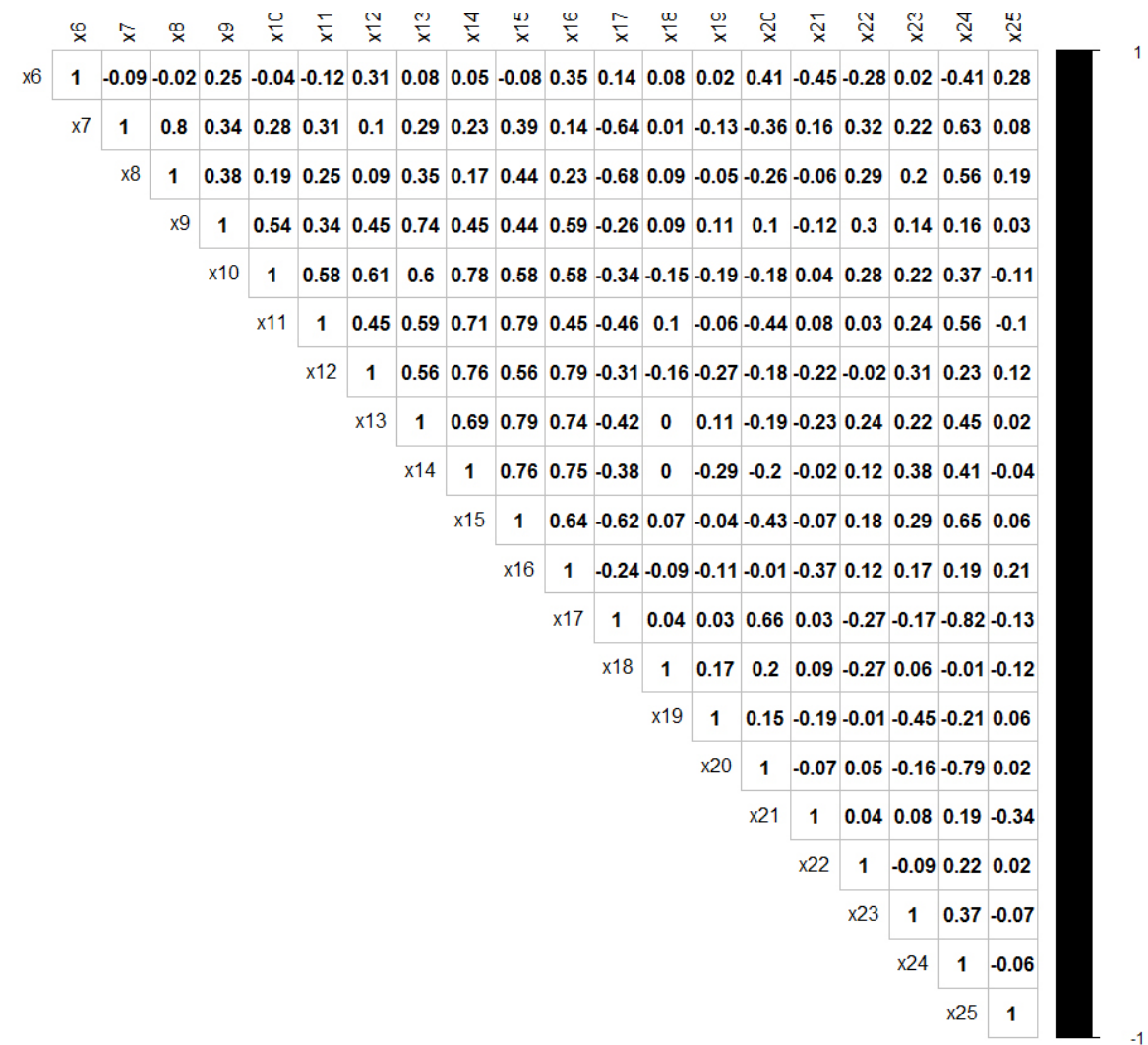

Figure 2: Correlation between quantitative climatic and flowering variables. 
Table 4: Selection of the best coffee yield explanatory models.

\begin{tabular}{ccc}
\hline Model & Structure & AIC \\
\hline Selec 1 & yield $\sim \mathrm{x} 1+\mathrm{x} 2+\mathrm{x} 5+\mathrm{x} 6+\mathrm{x} 13+\mathrm{x} 17+\mathrm{x} 21$ & 500.2 \\
Selec 2 & yield $\sim \mathrm{x} 1+\mathrm{x} 2+\mathrm{x} 5+\mathrm{x} 6+\mathrm{x} 10+\mathrm{x} 17+\mathrm{x} 21$ & 502.5 \\
\hline
\end{tabular}

Added to main flowering, mean flowering has a positive correlation with yield. Therefore, it was decided to investigate the climatic factors that impact this flowering. Again, two models showed remarkably close AIC (Table 8).

Table 5: Regression coefficients of the generalized linear model adjusted to coffee yield (model Selec 1).

\begin{tabular}{|c|c|c|c|c|c|c|}
\hline Variable & & Estimate & Standard deviation & t-value & $\mathrm{p}$-value & \\
\hline \multirow[t]{10}{*}{ Municipality } & x1Alfenas & 4.470531 & 0.792457 & 5.641 & 4.12E-07 & $* * *$ \\
\hline & x1Cabo_Verde & 4.356749 & 0.811567 & 5.368 & $1.18 \mathrm{E}-06$ & $* * *$ \\
\hline & x1Campestre & 4.06801 & 0.778057 & 5.228 & $2.00 \mathrm{E}-06$ & $* * *$ \\
\hline & x1Carmo.R.C & 4.278196 & 0.812525 & 5.265 & $1.74 \mathrm{E}-06$ & $* * *$ \\
\hline & x1Coromandel & 4.547211 & 0.779247 & 5.835 & $1.93 \mathrm{E}-07$ & $* * *$ \\
\hline & x1Guaxupe & 4.097961 & 0.807115 & 5.077 & $3.54 \mathrm{E}-06$ & $* * *$ \\
\hline & x1Monte.Carm & 4.658223 & 0.805857 & 5.78 & $2.40 \mathrm{E}-07$ & $* * *$ \\
\hline & x1Monte.S.M & 3.899442 & 0.79862 & 4.883 & $7.30 \mathrm{E}-06$ & $* * *$ \\
\hline & x1Nova.Res & 4.347934 & 0.757605 & 5.739 & $2.82 \mathrm{E}-07$ & $* * *$ \\
\hline & x1Rio.Par & 4.45044 & 0.782676 & 5.686 & $3.46 \mathrm{E}-07$ & $* * *$ \\
\hline Biennial period & $\mathrm{x} 2$ & 0.20885 & 0.050319 & 4.151 & 0.006767 & $* * *$ \\
\hline Flor_med_2 & $\mathrm{x} 5$ & 0.161604 & 0.07383 & 2.189 & 0.032262 & $*$ \\
\hline umi8.2 & $\mathrm{x} 17$ & 0.005985 & 0.006957 & 0.86 & 0.517045 & \\
\hline somchu1.3a3.3 & $\mathrm{x} 21$ & 0.000199 & 0.000122 & 1.623 & 0.094553 & . \\
\hline
\end{tabular}

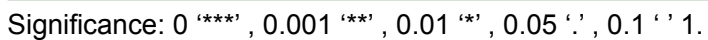

Biennial period: biennial; Flor_med_2: average flowering year 2; umi8.2: humidity august year 2; somchuv1.3a3.3: sum of rain from January to march year 3 .

Table 6: Regression coefficients of the generalized linear model adjusted to coffee yield (model Selec 2).

\begin{tabular}{|c|c|c|c|c|c|c|}
\hline Variable & & Estimate & Standard deviation & t-value & $\mathrm{p}$-value & \\
\hline \multirow[t]{10}{*}{ Municipality } & x1Alfenas & 4.769566 & 1.012839 & 4.709 & $1.38 \mathrm{E}-05$ & $* * *$ \\
\hline & x1Cabo_Verde & 4.67534 & 1.012302 & 4.619 & $1.92 \mathrm{E}-05$ & $* * *$ \\
\hline & x1Campestre & 4.385641 & 0.979614 & 4.477 & 3.19E-05 & $* * *$ \\
\hline & x1Carmo.R.C & 4.598742 & 1.031661 & 4.458 & $3.41 \mathrm{E}-05$ & $* * *$ \\
\hline & $\mathrm{x} 1$ Coromandel & 4.755452 & 0.966166 & 4.922 & $6.32 \mathrm{E}-06$ & $* * *$ \\
\hline & x1Guaxupe & 4.386492 & 1.012698 & 4.331 & 5.33E-05 & $* * *$ \\
\hline & x1Monte.Carm & 4.818361 & 0.976242 & 4.936 & $6.01 \mathrm{E}-06$ & $* * *$ \\
\hline & x1Monte.S.M & 4.16856 & 0.999152 & 4.172 & $9.27 \mathrm{E}-05$ & $* * *$ \\
\hline & x1Nova.Res & 4.660141 & 0.959866 & 4.855 & 8.09E-06 & $* * *$ \\
\hline & x1Rio.Par & 4.667934 & 0.963721 & 4.844 & 8.44E-06 & $* * *$ \\
\hline Biennial period & $\mathrm{x} 2$ & 0.228743 & 0.052388 & 4.366 & $4.71 \mathrm{E}-05$ & $* * *$ \\
\hline Flor_med_2 & $\mathrm{x} 5$ & 0.178283 & 0.074484 & 2.394 & 0.01963 & $*$ \\
\hline umi8.2 & $\mathrm{x} 17$ & 0.001446 & 0.007087 & 0.204 & 0.83895 & \\
\hline somchu1.3a3.3 & $\mathrm{x} 21$ & 0.000334 & 0.000134 & 2.498 & 0.01505 & $*$ \\
\hline
\end{tabular}

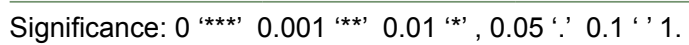

Biannual: biennial; Flor_med_2: average flowering year 2; umi8.2: humidity august year 2; somchuv1.3a3.3: sum of rain from January to march year 3. 
Table 7: Regression coefficients of the generalized linear model adjusted to coffee yield.

\begin{tabular}{lccccccc}
\hline Model & Variable & & Estimate & Standard deviation & t-value & p-value \\
\hline Selec1 & per_flores_2 & x6 & -0.00343 & 0.001287 & -2.662 & 0.001885 & $* *$ \\
Selec1 & Med.tmax9.1a12.1 & x13 & -0.06402 & 0.024358 & -2.628 & 0.006372 & $*$ \\
Selec2 & per_flores_2 & x6 & -0.0039 & 0.001283 & -3.036 & 0.00346 & $*$ \\
Selec2 & maio.tmax.1.2a4.2 & $\mathrm{x} 10$ & -0.0582 & 0.026239 & -2.218 & 0.03009 & $*$ \\
\hline
\end{tabular}

Significance: 0 (***) 0.001 (**) 0.01 ‘*’ 0.05 ‘' 0.1 “' 1 .

Per_flores_2: flowering period year 2; Med.tmax9.1a12.1: Mean maximum temperature from September to December year 1; maio.tmax.1.2a4.2: higher maximum temperature from January to April year 2.

Table 8: Selection of the best explanatory models of mean flowering.

\begin{tabular}{ccc}
\hline Model & Structure & AIC \\
\hline Selec 1 & flormed $\sim \mathrm{x} 6+\mathrm{x} 9$ & 14.8 \\
Selec 2 & flormed $\sim \mathrm{x} 6+\mathrm{x} 9+\mathrm{x} 23$ & 13.2 \\
\hline
\end{tabular}

Flormed: mean flowering.

According to Table 9, the occurrence of mean flowering showed a positive correlation with the flowering period $(p<0.01)$, for the Selec 1 and Selec 2 models, respectively), meaning that the chances of obtaining mean flowering increase, the longer the flowering period. The maximum temperature (x9) negatively correlated with the occurrence of flowering $(p<0.01)$, for models Selec 1 and Selec 2, respectively), correspondingto the formation period of vegetative buds.

\section{DISCUSSION}

Regarding climate and production variables, the results found in this study were confirmed by Picini et al. (1999) through the generation of coefficients that indicated interference of the yield of the previous year in the yield of the following year. This fact is due to the simultaneous occurrence of vegetative and reproductive functions in the same branch of coffee trees, contributing to the existence of alternating years of low and high production (Camargo; Camargo, 2001).

The positive correlation between yield and the variables mean flowering and sum of rain, in the bean formation phase (Table 4 and 5), can be justified by the years with multiple blooms and low intensity that affect yield once, during the stage of fruit filling and ripening, the nutritional requirements of these fruits vary according to their phase.

According to Soares et al. (2005), coffee presents a form of gregarious flowering, when every plant in a given region blooms practically together, in different quantities and intensities, generally decreasing. Despite this fact, this study demonstrates that, although the intensity of other flowering besides the main one is lower, it is relevant that the mean flowering occurs for the obtention of higher yield. Small flowering did not interfere in yield.

During bean formation phase, there is the solidification of the internal liquids of the grain and greater water demand of the plant (Camargo; Camargo, 2001), justifying the positive effects of rain from January to March.Machado et al. (2020) discussed that the plant leads its reserves of carbohydrates and substances produced in photosynthesis for fruit development. Thus, the absence or rain reduction in this period could end in the low accumulation of dry mass and generate small fruits or even their early fall (Alves; Livramento, 2003).

This phase was considered critical by Silva et al. (2016), who identified lower production in municipalities in Minas Gerais in 2001, when the rain occurred with low intensity, as for bean formation and filling, water availability is an essential factor (Rezende et al., 2011).

The negative influence of flowering period (x6) on yield can be assigned to the possibility that, the greater the distance between the first and the last flowering of the coffee tree, the greater the chances of more flowering, but with less intensity, which causes the fruits to become uneven. Chalfoun (2010) observed several flowering events within the same cycle, causing lower fruit homogeneity and, consequently, asynchronous development and maturation. According to Caldas et al. (2018), in addition to compromising the efficiency and yield of the harvest, these factors generate impacts on production costs and beverage quality (Barreto et al., 2018).

The negative correlation of maximum temperature from September to December (x13) and January to April (x10) with yield, is due to the fact that its occurrence corresponds to the first phenological phase with the formation of vegetative buds and the beginning of induction in the plant, resulting in yield losses that will be felt in the next harvest (Table 6).

The study by Martins et al. (2015) indicates that high temperatures increase arabica coffee yield. However, the temperature variation during the cycle of most crops and the different requirements in distinct phenological phases of the plants make it necessary to consider the plant phenological cycle to avoid wrong conclusions (Carvalho et al., 2014). According to Asthir (2015), the stress suffered by exposure to high temperatures can decrease the plant metabolism by interfering 
Table 9: Regression coefficients of the generalized linear model adjusted to the presence of the mean flowering.

\begin{tabular}{ccccccc}
\hline Models & Variables & Coefficients & Estimate & Standard deviation & p-value \\
\hline Selec1 & x6=per_flores_2 & x6 & 1.2712 & 0.5896 & 0.0311 & $*$ \\
Selec1 & x9=maio.tmax9.1a12.1 & x9 & -1.4461 & 0.6651 & 0.0297 & $*$ \\
Selec2 & x6=per_flores_2 & x6 & 2.1301 & 1.2781 & $8.26 \mathrm{e}-07$ & $* * *$ \\
Selec2 & x9=maio.tmax9.1a12.1 & x9 & -2.4615 & 1.4609 & $<2.2 \mathrm{e}-16$ & $* * *$ \\
Selec2 & $\mathrm{x} 23=$ maior.d.hidr.1.2a4.2 & $\mathrm{x} 23$ & 0.1991 & 0.132 & 0.05906 & \\
\hline
\end{tabular}

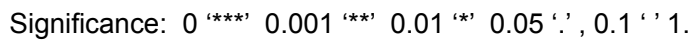

Per_flores_2: flowering period year 2; maio.tmax9.1a12.1: higher maximum temperature from September to December year 1; maior.d.hidr.1.2a4.2: higher water deficit from January to April year 2.

with electron transport and reducing the effectiveness of photosynthesis. Also, Oliveira et al. (2012) reinforce that high exposure to the sun can affect metabolism, reducing coffee yield, predisposing the plant to the manifestation of diseases such as Cercosporiosis (Cercospora coffeicola).This result confirms the importance of temperature in the phenological cycle of coffee and its interference in each stage (GaspariPezzopane et al., 2009).

According to Rena and Barros (2004), it is common for up to four blooms to occur in most coffee plantations in Brazil, which results in splitting the fruit development that happens in a non-simultaneous way (Barros; Maestri; Rena,1999). Hence, this non-synchronized development of the beans can minimize the depletion of coffee reserves (carbohydrates), contributing to the next vegetative period of the plant (Damatta et al., 2007).However, in this study, it was observed that mean flowering, summed with main flowering, presented a positive correlation with yield.

Despite being one of the most important physiological processes of coffee (Barros; Maestri; Coons, 1978), flowering is still a poorly understood event with a complex biochemical, physiological and morphological composition associated with various aspects, such as temperature, light, soil, water availability and plant genetics (Rena; Barros, 2004).

Information about the influence of environmental factors on coffee flowering and growth is complex (Castanheira et al., 2012) once, during the coffee reproductive cycle, successive flowering can occur, which also depends on plant physiology, crop location and management (Rena; Maestri, 1987; Souza, 2016). Main flowerings are generally well defined and occur due to severe water deficiency in the bud resting phase, followed by rainfall and a drop in average temperature. Studies by Gaspari-Pezzopane et al. (2009) indicate that the absence of a marked water deficit may be one of the responsible factors for the remaining flowering in the reproductive period.

Although there is not a single environmental factor that acts on flowering (Barros et al., 1978), the negative correlation between maximum temperature and flowering in this study is associated with the formation of vegetative buds. Assad et al. (2004) state that temperature is one of the most important elements to be considered in the definition of the coffee agricultural potential of a region, since high temperatures reduce plant development capacity. The flower buds start at different times of the reproductive growth phase, with evidence that high temperatures impair both the vegetative and reproductive development of the coffee tree, culminating in damage to the leaves in the case of temperatures between $28{ }^{\circ} \mathrm{C}$ and $33^{\circ} \mathrm{C}$ for extended periods (Franco, 1956; Drinnan; Menzel, 1995).

\section{CONCLUSIONS}

Statistical models confirmed that coffee yield in Southern Minas Gerais and Alto Paranaíba regions varies according to the biennial cycle, main flowering, mean flowering, flowering period, and rain during the bean formation phase. It was observed that the main flowering occurs every year, unlike mean and small flowers. The mean flowering, for example, is linked to the length of the coffee flowering period. The occurrence of mean flowering added to the main flowering resulted in higher yield, but small flowering was not significant. In the vegetative bud formation phase, yield and mean flowering are inversely related to the maximum temperature. This study was limited to analyzing the influence of flowering and climatic data on coffee yield. However, the selected models are useful tools to guide input handling and acquisition techniques, resulting in greater yield from the available resources.

\section{ACKNOWLEDGMENTS}

The authors would like to thank the Regional Cooperative of Coffee Growers in Guaxupé - COOXUPÉ and the Technical Assistance and Rural Extension Company of the State of Minas Gerais - EMATER, for their contributions to this study. 


\section{REFERENCES}

ALVES, J. D.; LIVRAMENTO, D. E. Morfologia e fisiologia do cafeeiro. Lavras: UFLA/FAEPE, 2003. 46p. (Texto acadêmico).

ARCILA-PULGARÍN, J. et al. Application of the extended BBCHscale for the description of the growth stages of coffee (Coffea spp.). Annals of Applied Biology, 141(1):19-27, 2002.

ASSAD, E. D. et al. Impacto das mudanças climáticas no zoneamento agroclimático do café no Brasil. Pesquisa Agropecuária Brasileira, 39(11):1057-1064, 2004.

ASTHIR, B. Mechanisms of heat tolerance in crop plants. Journal of Plant Interactions, 10(1):202-210, 2015.

BARRETO, H. G. et al. Expression analysis of the coffee (Coffea arabica L.) FRIGIDA4-like GENE (CaFRL4). Revista Desafios, 5:204-213, 2018.

BARROS, R. S.; MAESTRI, M.; COONS, M. P. The physiology of flowering in coffee: A review. Journal of Coffee Research, 8(2-3):29-73, 1978.

BARROS, R. S.; MAESTRI, M.; RENA, A. B. Physiology of growth and production of the coffee tree - A review. Journal of Coffee Research, 27(1):1-54, 1999.

BONGASE, E. D. Impacts of climate change on global coffee production industry: Review. African Journal of Agricultural Research, 12(19):1607-1611, 2017.

CALDAS, A. L. D. et al. Produtividade e qualidade de café cv. travessia em resposta à irrigação e adubação fosfatada. Revista Brasileira de Agricultura Irrigada, 12(1):23572365, 2018.

CAMARGO, A. P. Balanço hídrico no Estado de São Paulo. Campinas: Instituto Agronômico, 1971. 28p.

CAMARGO, A. P. Florescimento e frutificação de café arábica nas diferentes regiões (cafeeiras) do Brasil. Pesquisa Agropecuária Brasileira, 20(7):831-839, 1985.

CAMARGO, A. P.; CAMARGO, M. B. P. Definição e esquematização das fases fenológicas do cafeeiro arábica nas condições tropicais do Brasil. Bragantia, 60(1):65-68, 2001.

CAMARGO, M. B. P. The impact of climatic variability and climate change on arabica coffee crop in Brazil. Bragantia, 69(1):239-247, 2010.

CARVALHO, V. L.; CHALFOUN, S. M. Manejo integrado das principais doenças do cafeeiro. Informe Agropecuário, 19(193):27-35, 1998.
CARVALHO, H. P. de et al. Classificação do ciclo de desenvolvimento de cultivares de cafeeiro através da soma térmica. Coffee Science, 9(2):237-244, 2014.

CASTANHEIRA, D. T. et al. Floração e potencial hídrico foliar de cafeeiros sob diferentes regimes hídricos e densidades de plantio. Coffee Science, 8(2):192-204, 2013.

CHALfOUN, S. M. Controle biológico e metabólitos microbianos bioativos: Uma perspectiva da qualidade do café. Ciência e Agrotecnologia, 34(5):1071-1085, 2010 .

COLLET, D. Modelling binary data. London, Chapman \& Hall, 1991. 369p.

COMPANHIA ENERGÉTICA DE MINAS GERAISCEMIG. Atlas solarimétrico de Minas Gerais. Belo Horizonte: Cemig, 2012. 80p.

COMPANHIA NACIONAL DE ABASTECIMENTO CONAB. Acompanhamento da safra brasileira de café. 2019. Brasília: Monitoramento Agrícola. Available in: $<$ https://www.conab.gov.br/info-agro/safras/cafe $>$. Access in: November, 14, 2020.

DAMATTA, F. M. et al. Ecophysiology of coffee growth and production. Brazilian Journal of Plant Physiology,19(4):485-510, 2007.

DAWID, J.; HAILU, G. Inorganic fertilizers requirement of coffee (Coffea arabica L.) - A review. Journal of Biology, Agriculture and Healthcare, 8(21):24-34, 2018.

DRINNAN, J. E.; MENZEL, C. M. Temperature affects vegetative growth and flowering of coffee (Coffea arabica L.). Journal of Horticultural Science, 70(1):25-34, 1995.

DUTRA NETO, C. et al. Indicação geográfica do planalto de Vitória da Conquista, denominação de origem para o café. Revista Extensão \& Cidadania, 4(7):103$114,2017$.

EMILIANO, P. C.; VIVANCO, M. J. F.; MENEZES, F. S. Information criteria: How do they behave in different models? Computational Statistics \& Data Analysis, 69:141-153, 2014.

FRANCO, C. M. Descoloração em folhas de cafeeiro causada pelo frio. Bragantia, 15(13):131-136, 1956.

GASPARI-PEZZOPANE, C. de et al. Atributos fenológicos e agronômicos em cultivares de cafeeiro arábica. Ciência Rural, 39(3):711-717, 2009. 
HAGGAR, J.; SCHEPP, K. Coffee and climate change: impacts and options for adaption in Brazil, Guatemala, Tanzania and Vietnam. Londres: Natural Resources Institute, 2012. 55p.

MACHADO, A. H. R. et al. A cultura do café (Coffea arabica) em sistema agroflorestal. Brazilian Journal of Animal and Environmental Research, 3(3):1357-1369, 2020.

MARTINS, E. et al. Influência das condições climáticas na produtividade e qualidade do cafeeiro produzido na região do Sul de Minas Gerais. Coffee Science, 10(4):499-506, 2015.

MES, M. G. Studies on the flowering of Coffea arabica $\mathbf{L}$. Nova Iorque: IBEC Research Institute, 1958. 39p.

NUNES, F. L. et al. Modelos agrometeorológicos de estimativa da duração do estádio floração-maturação para três cultivares de café arábica. Bragantia, 69(4):1011$1018,2010$.

OLIVEIRA, K. M. G. et al. Modelagem para a estimativa da orientação de linhas de plantio de cafeeiros. Engenharia Agrícola, 32(2):293-305, 2012.

PICINI, A. G. et al. Desenvolvimento e teste de modelos agrometeorológicos para a estimativa de produtividade do cafeeiro. Bragantia, 58(1):157-170, 1999.

R DEVELOPMENT CORE TEAM. R: A language and environment for statistical computing. $\mathrm{R}$ foundation for statistical computing. 2020. Version 4.0.1.2020. Vienna: Austria. Available in: <https://www.R-project.org/>. Access in: September, 5, 2020.
RENA, A. B.; BARROS, R. S. Aspectos críticos no estudo da floração do café. In: ZAMBOLIM, L. (ed.). Efeitos da irrigação sobre a qualidade e produtividade do café. Viçosa: Universidade Federal de Viçosa, p.149172. 2004.

RENA, A. B.; MAESTRI, M. Ecofisiologia do cafeeiro. In: CASTRO, P. R. C. et al. Ecofisiologia da produção agrícola. Piracicaba: Associação Brasileira para Pesquisa da Potassa e do Fosfato, p.119-147. 1987.

REZENDE, F. C. et al. Coffee pruning and differents irrigation periods: Productivity and quality. Coffee Science, 5(3):229-36, 2011.

SILVA, W. et al. Identificação de períodos secos e chuvosos e a influência na produção de café de montanha nas matas de Minas. Climatologia e Estudos da Paisagem, 9(1):117,2016 .

SILVA, M. D. R. R. et al. Vulnerabilidad de la producción del café (Coffea arabica L.) al cambio climático global. Terra Latinoamericana, 31(4):305-313, 2013.

SOARES, A. R. et al.Irrigação e fisiologia da floração em cafeeiros adultos na região da Zona da Mata de Minas Gerais. Acta Scientiarum Agronomy, 27(1):117-125, 2005.

SOUZA, J. M. de Supressão da irrigação no café conilon. Agrarian Academy, 3(6):65-78, 2016.

VERDIN FILHO, A. C. et al. New management technology for arabica coffee: The cyclic pruning program for arabica coffee. Coffee Science, 11(4):475-483, 2016. 